\title{
Temporal, spatial and spatiotemporal analysis of the occurrence of visceral leishmaniasis in humans in the City of Birigui, State of São Paulo, from 1999 to 2012
}

\author{
Carolina Portugal Vieira ${ }^{[1]}$, Agda Maria Oliveira ${ }^{[2]}$, \\ Lilian Aparecida Colebrusco Rodas ${ }^{[3],[4]}$, Margareth Regina Dibo ${ }^{[5]}$, \\ Marluci Monteiro Guirado ${ }^{[5]}$ and Francisco Chiaravalloti Neto ${ }^{[6]}$
}

[1]. Curso de Graduação em Enfermagem, Escola de Enfermagem, Universidade de São Paulo, São Paulo, SP. [2]. Programa de Pós-Graduação em Saúde Pública, Faculdade de Saúde Pública, Universidade de São Paulo, São Paulo, SP. [3]. Programa de Pós-Graduação em Ciência Animal, Universidade Estadual Paulista Júlio de Mesquita Filho, Araçatuba, SP. [4]. Superintendência de Controle de Endemias, Secretaria de Estado de Saúde de São Paulo, Regional de Araçatuba, Araçatuba, SP. [5]. Laboratório de Vetores de São José do Rio Preto, Superintendência de Controle de Endemias, Secretaria de Estado de Saúde de São Paulo, São José do Rio Preto, SP. [6]. Departamento de Epidemiologia, Faculdade de Saúde Pública, Universidade de São Paulo, São Paulo, SP.

Introduction: In 1999, Birigui and Araçatuba were the first municipalities in the State of São Paulo to present autochthonous cases of visceral leishmaniasis in humans (VLH). The aim of this study was to describe the temporal, spatial and spatiotemporal behaviors of VLH in Birigui. Methods: Secondary data were obtained from the Notifiable Diseases Information System from 1999 to 2012. The incidence, mortality and case fatality rates by sex and age were calculated. The cases of VLH were geocoded and grouped according to census tracts. Local empirical Bayesian incidence rates were calculated. The existence of spatial and spatiotemporal clusters was investigated using SaTScan software. Results: There were 156 confirmed cases of autochthonous VLH. The incidence rate was higher in the 0-4-year-old children, and the mortality and case fatality rates were higher in people aged 60 years and older. The peaks of incidence occurred in 2006 and 2011. The Bayesian rates identified the presence of VLH in all of the census tracts in the municipality; however, spatial and spatiotemporal clusters were found in the central area of the municipality. Conclusions: Birigui, located in the Araçatuba region, has recently experienced increasing numbers of VLH cases; this increase is contrary to the behavior observed over the entire region, which has shown a decreasing trend in the number of VLH cases. The observations that the highest incidence is in children 0-4 years old and the highest mortality is in people 60 years and older are in agreement with the expected patterns of VLH.

Keywords: Visceral leishmaniasis. Temporal analysis. Spatial analysis.

\section{INTRODUCTION}

Visceral leishmaniasis (VL), or kala-azar, is a parasitic disease that is widely distributed worldwide and is mainly found in tropical and subtropical Asia, the Middle East, Africa, and the Americas ${ }^{1}$. According to the Pan American Health Organization (PAHO $)^{2}, 38,808$ cases of visceral leishmaniasis in humans (VLH) were reported in the Americas from 2001 to 2011; 96.6\% of those cases occurred in Brazil.

In Brazil, VL is present in 26 states of the five regions of the Brazilian territory ${ }^{2-5}$. Since 1980, there has been a change in the epidemiological pattern of VL, which was previously characterized as a rural disease. With the urbanization of Lutzomyia longipalpis (Lutz \& Neiva, 1912), the main vector of the parasite in the Americas ${ }^{6,7}, \mathrm{VL}$ is now present in urban areas.

Address to: Dr. Francisco Chiaravalloti Neto. Dept ${ }^{\circ}$ Epidemilogia/FSP/USP. Av. Dr. Arnaldo 715, 01246-904 São Paulo, SP, Brasil.

Phone: 55 113061-7920; Fax: 5511 3061-7926

e-mail: franciscochiara@usp.br

Received 28 March 2014

Accepted 16 June 2014
The vector Lu. longipalpis was first identified in 1997 in the western region of the State of São Paulo in the municipality of Araçatuba ${ }^{8}$. However, the first autochthonous cases of VLH were recorded in 1999 in the municipalities of Araçatuba and Birigui ${ }^{9}$. Thereafter, VLH spread to other municipalities, particularly in the western region of the state; between 1999 and 2011, 73 municipalities of São Paulo had human cases $^{10}$ and 125 municipalities documented the presence of the vector ${ }^{11}$.

Due to its high incidence of VLH over recent years, Birigui is considered a municipality with intense VLH transmission and is a priority area for the surveillance and control of this disease in the state of São Paulo ${ }^{12}$. Thus, the objective of this study was to describe the temporal and spatial occurrence of VLH in this municipality, to identify spatial and spatiotemporal clusters of VLH cases and to pinpoint the areas of greatest risk for its occurrence.

\section{METHODS}

This descriptive study was performed in the City of Birigui $\left(21^{\circ} 15^{\prime} 49^{\prime \prime}\right.$ South, 50 $21^{\prime} 10^{\prime \prime}$ West), which had an average annual temperature of $23^{\circ} \mathrm{C}$, an annual accumulated rainfall of $1229.5 \mathrm{~mm}$, and 108,728 inhabitants in 2010 . Birigui is located 
in the western region of the São Paulo state and is part of the administrative region (AR) of Araçatuba.

The source of information on the occurrence of autochthonous cases of VLH in Birigui during the period of 1999-2012 was the Notifiable Diseases Information System (SINAN) database, which was provided by the surveillance system of the municipality. The following information was considered for VLH cases: date of onset of symptoms, age, sex and address. The information source for the number of inhabitants, age and sex of the entire municipality, and its census tracts was the Brazilian Institute of Geography and Statistics (IBGE).

The incidence, mortality and case fatality rates were calculated overall and by sex and were age-standardized for the entire study period. These rates were also calculated by age and sex. Additionally, the overall incidence rates and incidence rates by sex were calculated and age-standardized for each individual year of the study. The VLH cases were geocoded based on the address from the database of Birigui addresses and grouped by urban census tracts. The incidence rates were obtained by census tracts and were age-standardized for each year. The incidence and mortality rates by census tracts, standardized by age for the entire study period, were also calculated. Thematic maps were created to represent the distribution of VLH cases in Birigui and to represent the incidence and mortality rates.

Bayesian empirical local rates for each urban census tract were estimated based on the number of cases that occurred throughout the study period and the population at the midpoint (2006) using the empirical Bayesian method available with TerraView 4.2.2 software $^{13}$. The neighborhood criterion considered sectors to be neighbors when they had at least one side or vertex in common. To verify the existence of spatial autocorrelation between the incidence rates of VLH for the entire study period, the global Moran index was calculated ${ }^{13}$.

Three databases were created to identify spatial and spatiotemporal clusters of VLH cases in Birigui from 19992012. The first database, which is called the bank of cases, contained each VLH case with the identification of the census tract and the onset date of the symptoms (month and year). The second database was a file containing population data for each census tract. The third database had plane Cartesian geographic coordinates of the centroid of each census tract. The three files were imported into SaTScan 9.1.1 software.

To identify purely spatial clusters, scan statistics were used on SaTScan, and a Poisson discrete model was constructed with the following conditions: time accuracy, in months, during the period of 1999-2012; non-occurrence of geographical overlap of the clusters; and maximum size cluster equal to $50 \%$ of the exposed population, with circular clusters and 999 replications ${ }^{14}$. To identify spatiotemporal clusters, a discrete Poisson model was used with the same conditions as the purely spatial analysis; this model considered the maximum size of the temporal cluster to be equal to $50 \%$ of the study period ${ }^{14}$. Next, the Birigui areas that were classified as spatial and spatiotemporal clusters were visited to identify their main characteristics in terms of property type; presence of backyards; vegetation and animals; and socioeconomic, demographic and environmental conditions.

\section{Ethical considerations}

This project was approved by the Ethics Committee of the Faculty of Public Health, University of São Paulo, by the Platform Brasil, CAAE: 14107313.3.3333.5421, Opinion Number: 257511 on 04/26/2013.

\section{RESULTS}

The first two cases of VLH in Birigui were confirmed in 1999; these cases were followed by a period of two years (2000 and 2001) in which no cases were documented (Figure 1A). After 2001, there was a rise in the incidence curve of VLH, culminating in a peak in 2006. This peak was followed by a fall in incidence and a new peak in 2011; the incidence rate in 2011 was higher than the incidence rate in 2006 (Figure 1A). From 1999-2012, 156 autochthonous cases were confirmed in the county, corresponding to a total incidence rate of 13.5 cases per 100,000 inhabitant-years; there were 12.8 cases per 100,000 inhabitant-years in males and 14.4 in females. Considering the entire study period, the VLH incidence rate was higher in children aged 0-4 years old (Figure 1B), and the mortality and case fatality rates were higher in people aged 60 years and older (Figures $\mathbf{1 C}$ and $\mathbf{D}$ ).

Although the distribution of VLH between genders was presented in a homogeneous fashion, further analysis of the incidence rates by gender and age revealed that girls aged 0-4 years were more affected than boys, and men aged between 20-59 years were more affected than women (Figure 1B). Furthermore, the case fatality and mortality rates were higher in men aged 60 years and older compared with women of a similar age (Figures 1C and D).

Of the total (156) confirmed cases in the period from 1999-2012, 153 (98.0\%) were geocoded. Three cases were not geocoded: one because it was located in a rural area and two because they did not have address information. As shown in Figure 2A, VLH cases occurred in 87 of the 156 census tracts of the urban area. Of all the census tracts with cases, the majority (50) had only one case; there were two or three cases in 30 census tracts, and there were four or five cases in six census tracts. Only one census tract had a higher concentration, with a total of nine cases. According to the census tracts, the incidence rates ranged from 0 to 78.38 cases per 100,000 inhabitant-years (Figure 2B). The global Moran index, which was calculated from these rates, was not statistically significant and showed that the distribution had random behavior.

Figure 2C shows the Bayesian incidence rate of VLH, which identified decreases in the amplitude and in the peak of incidence and also identified the presence of the disease in all of the census tracts. According to the census tracts, the mortality rates ranged from 0 to 31.26 cases per 100,000 inhabitant-years (Figure 2D), and the global Moran index, which was calculated from these rates, was not statistically significant, showing that the distribution had random behavior.

Figure 3 and Figure 4 show the expansion process of VLH cases in the municipality of Birigui during the period 


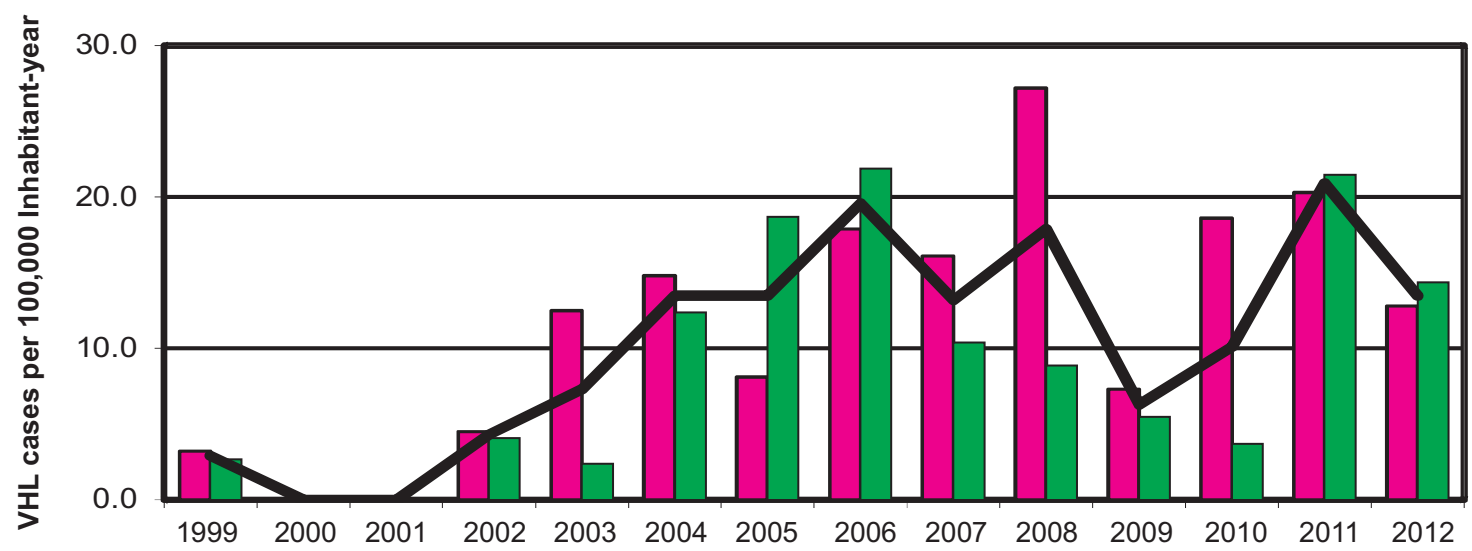

(A)
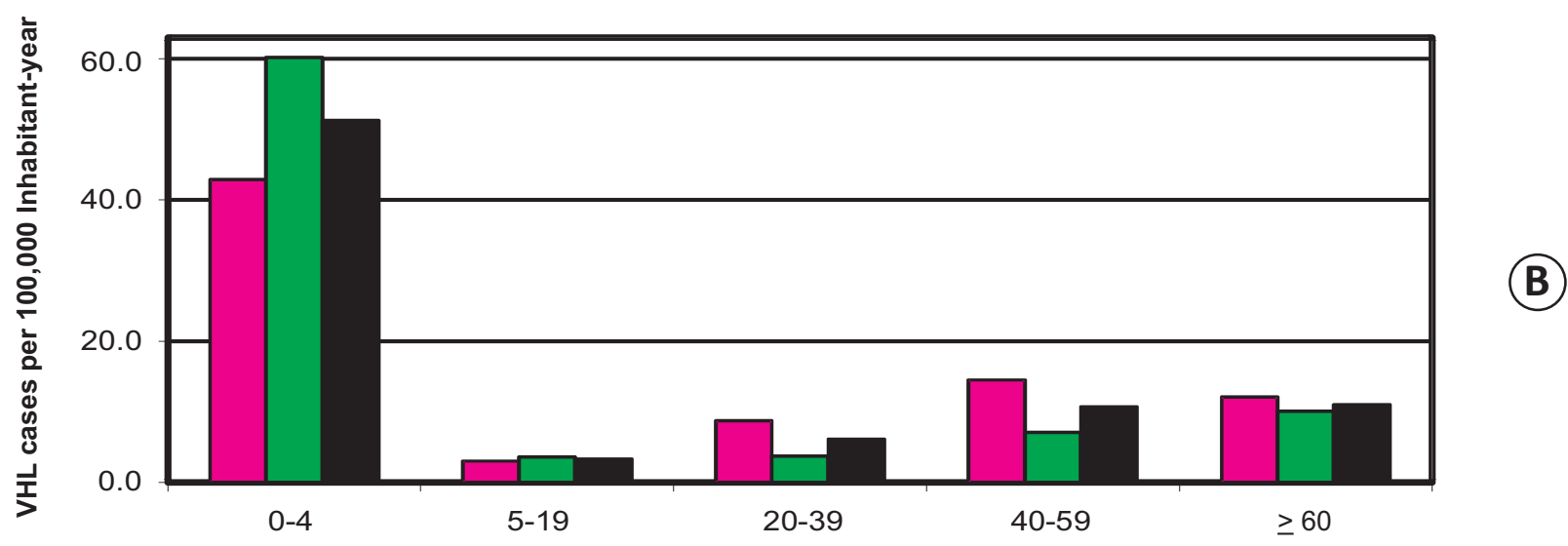

(C)
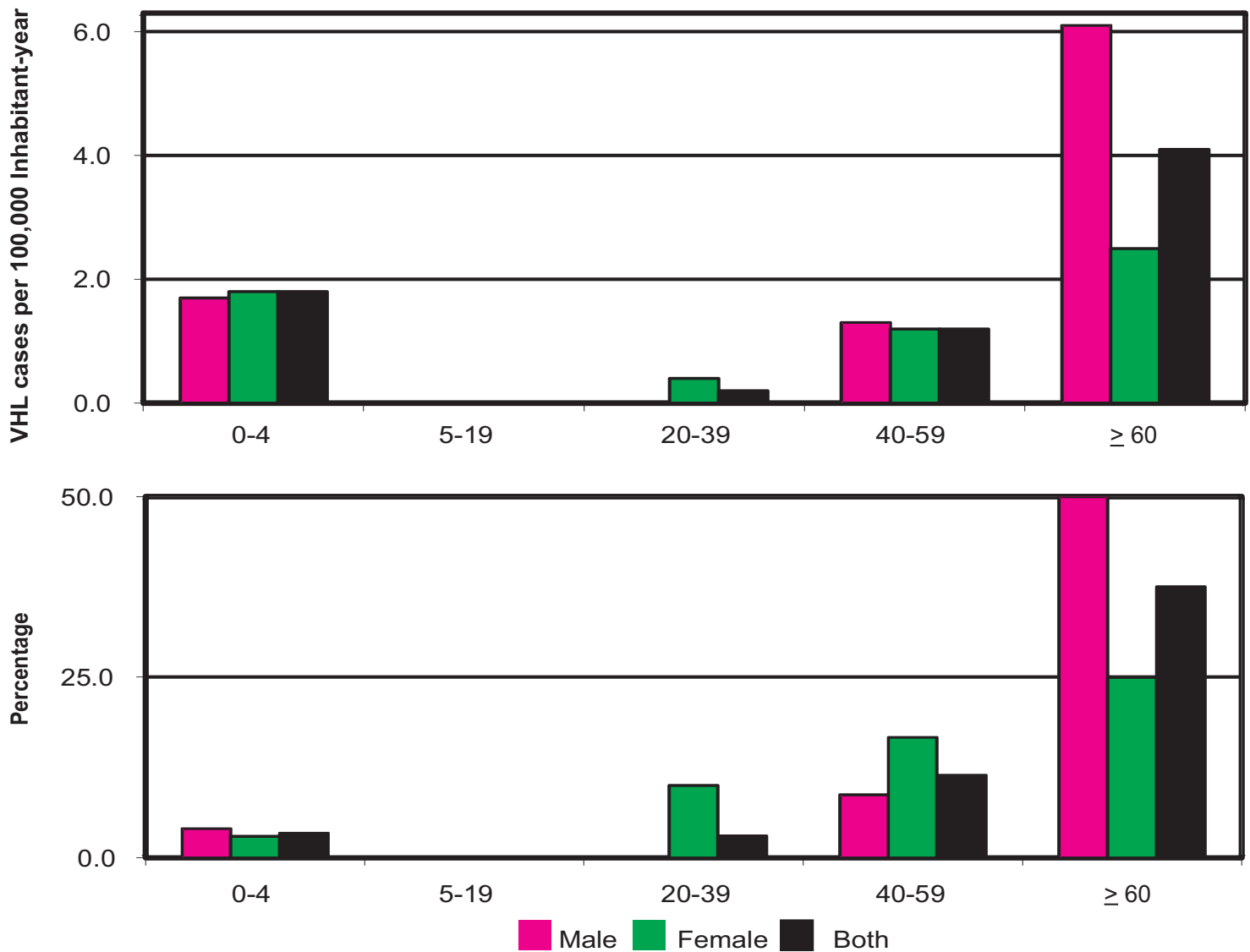

(D)

FIGURE 1 - Incidence rates of visceral leishmaniasis in humans (VLH) by sex and year (A); incidence rates (B), mortality rates (C) and case fatality rates of VLH (D) by sex and age for the entire study period, 1999-2012, Birigui, State of São Paulo, Brazil. 
- VLH cases - 1999 to 2012

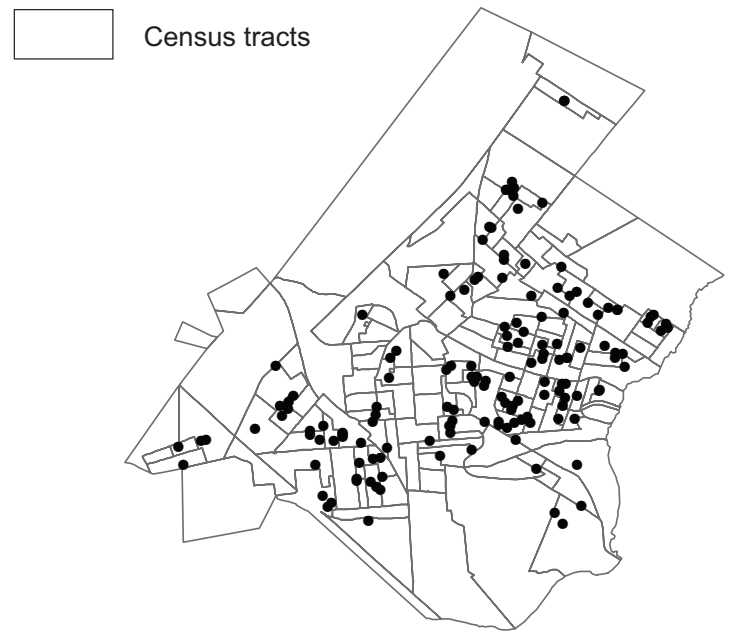

(A)

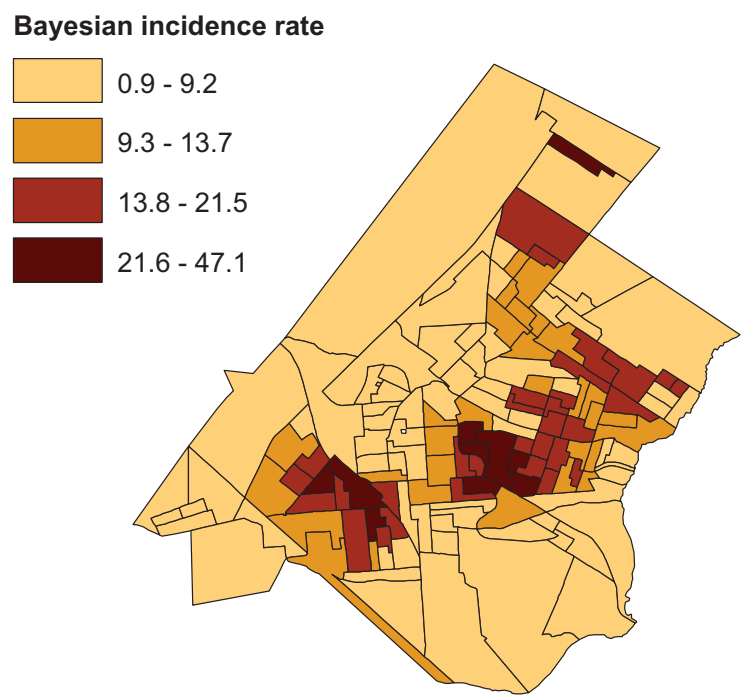

(C)

- VLH cases - 1999 to 2012

(E)

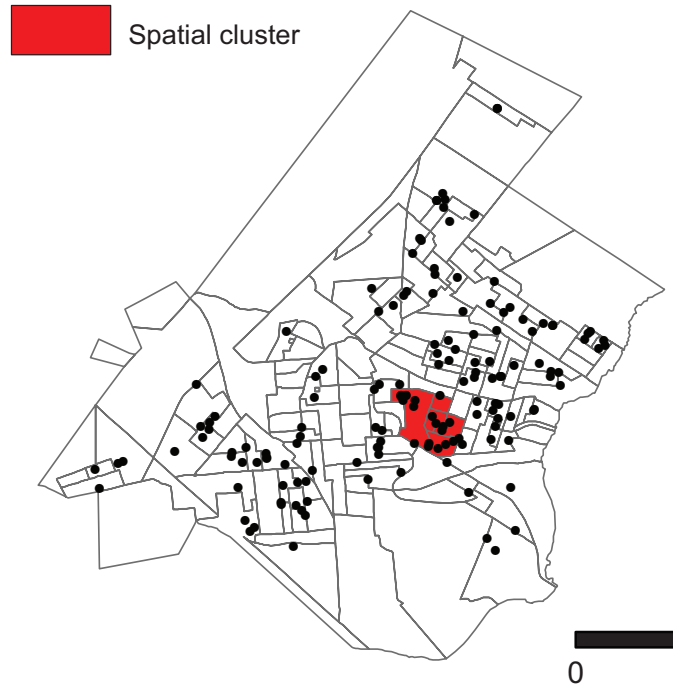

Incidence rate

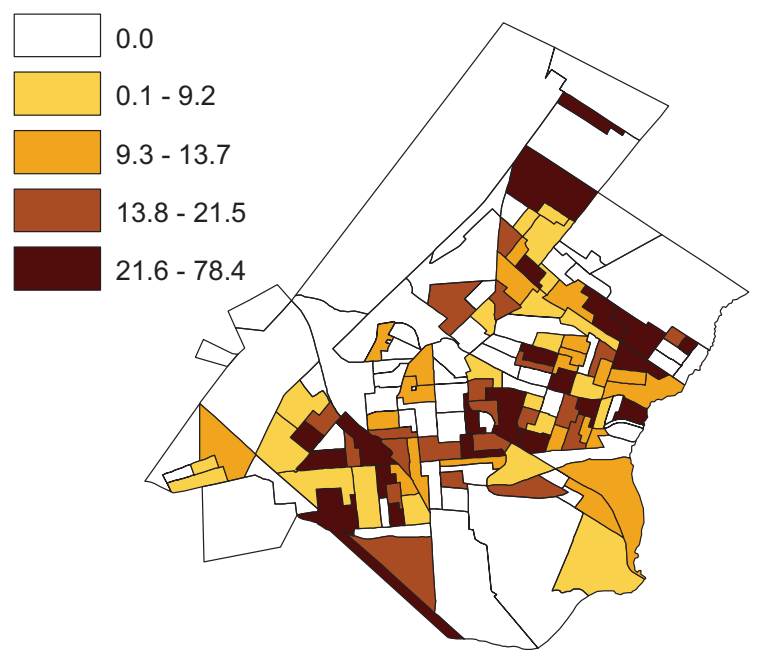

Mortality rate

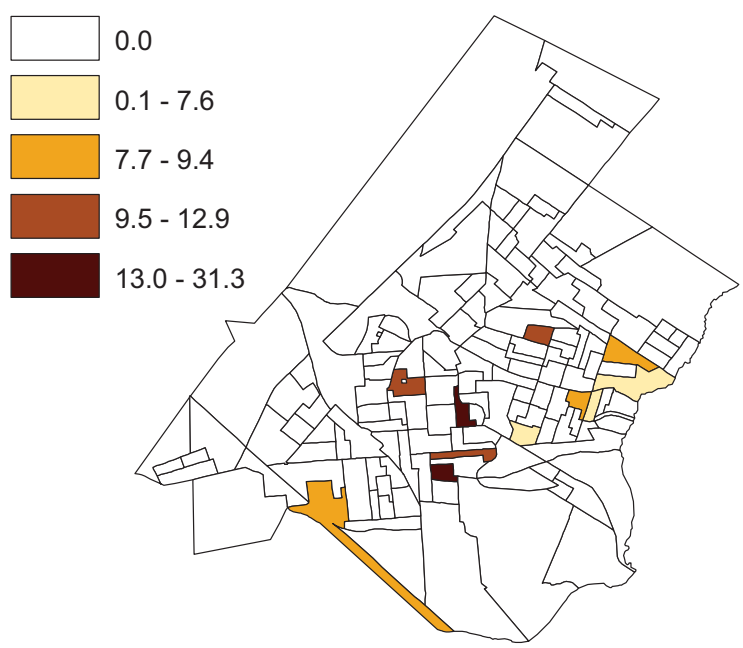

- VLH cases - Feb/2006 to Sep/2012

Spatial-temporal cluste

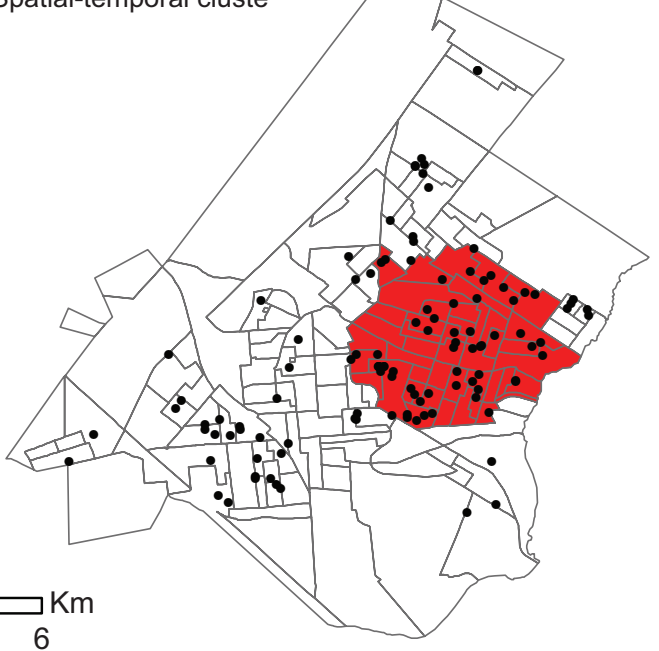

(B)

(D)

FIGURE 2 - Cases of visceral leishmaniasis in humans (VLH) (A); incidence rates (B), empirical Bayesian incidence rates (C) and mortality rates (D) of VLH per 100,000 inhabitant-years; spatial clusters (E) and spatio-temporal clusters (F) of VLH, 1999-2012, Birigui, State of São Paulo, Brazil. 
(A)
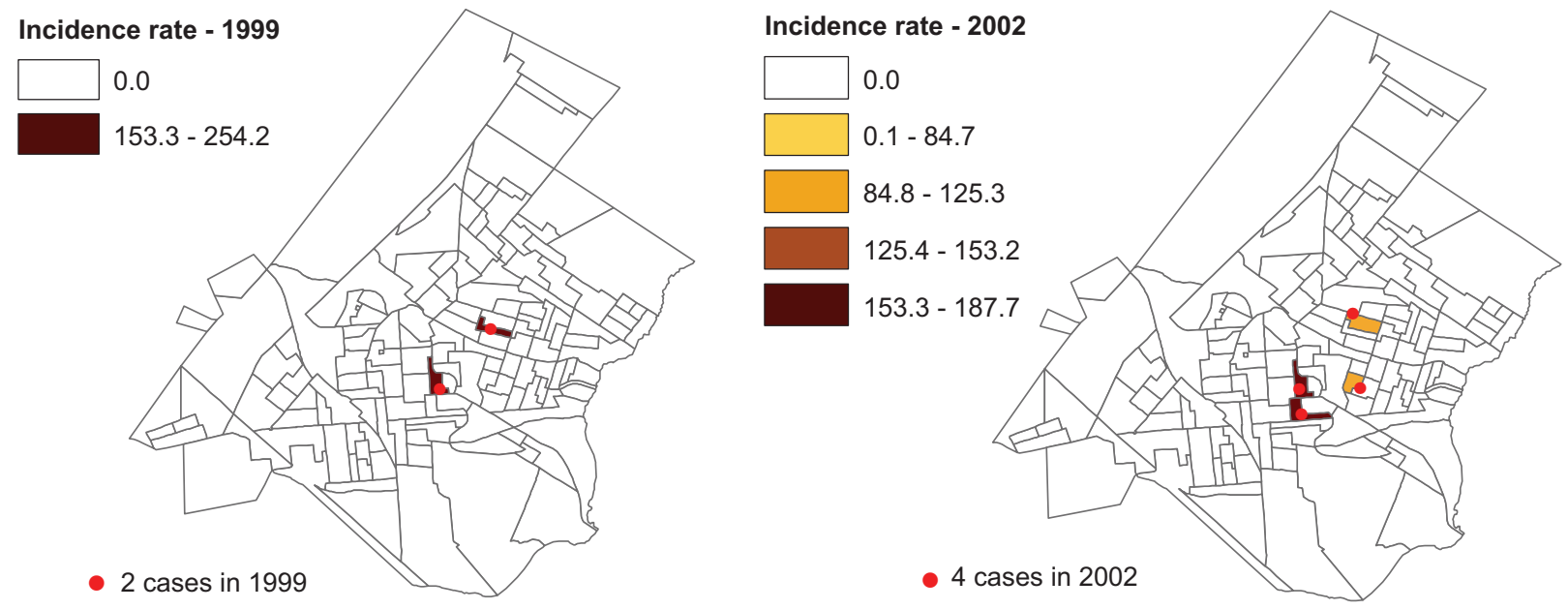

(B)

Incidence rate - 2003

Incidence rate - 2004
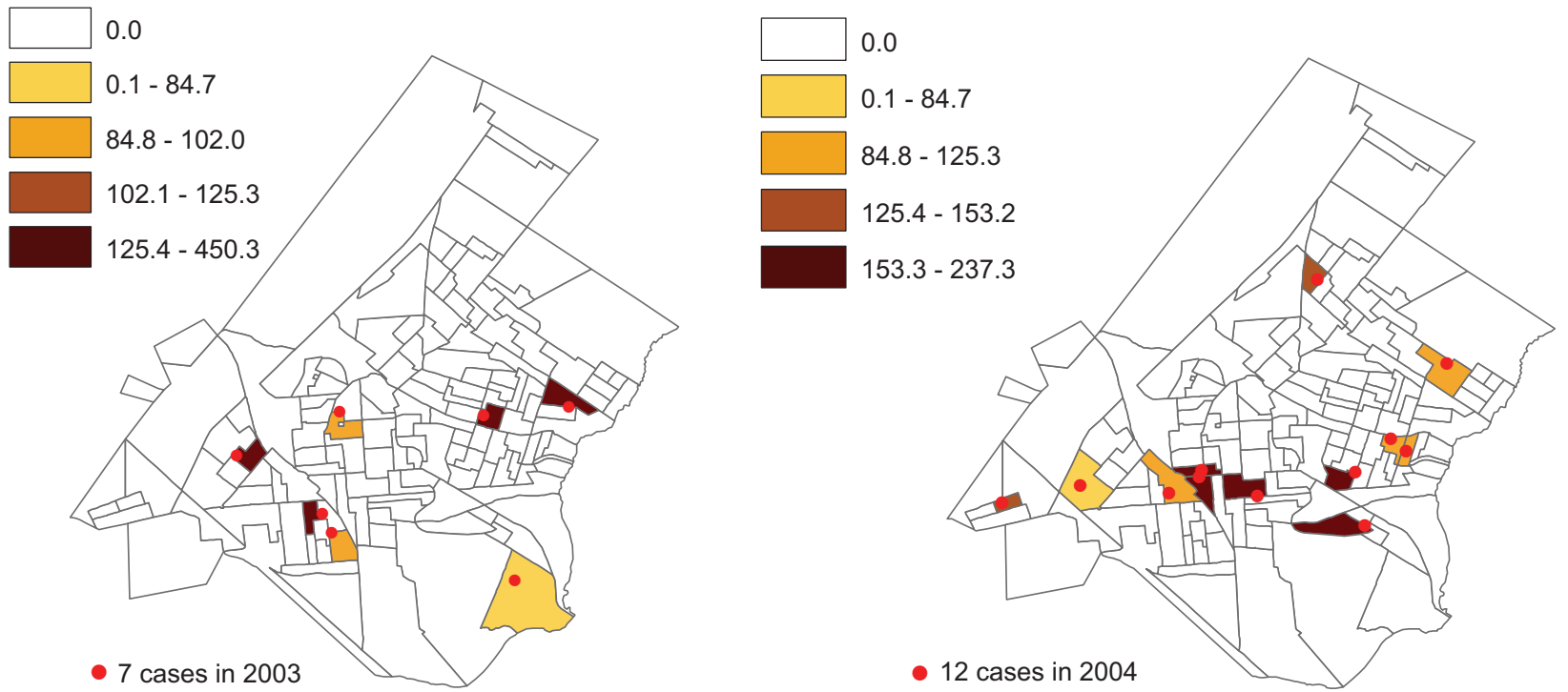

(D)

Incidence rate- 2005

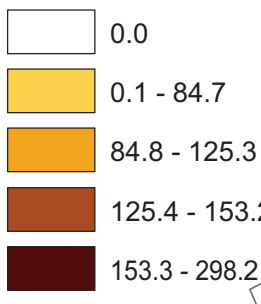

(E)

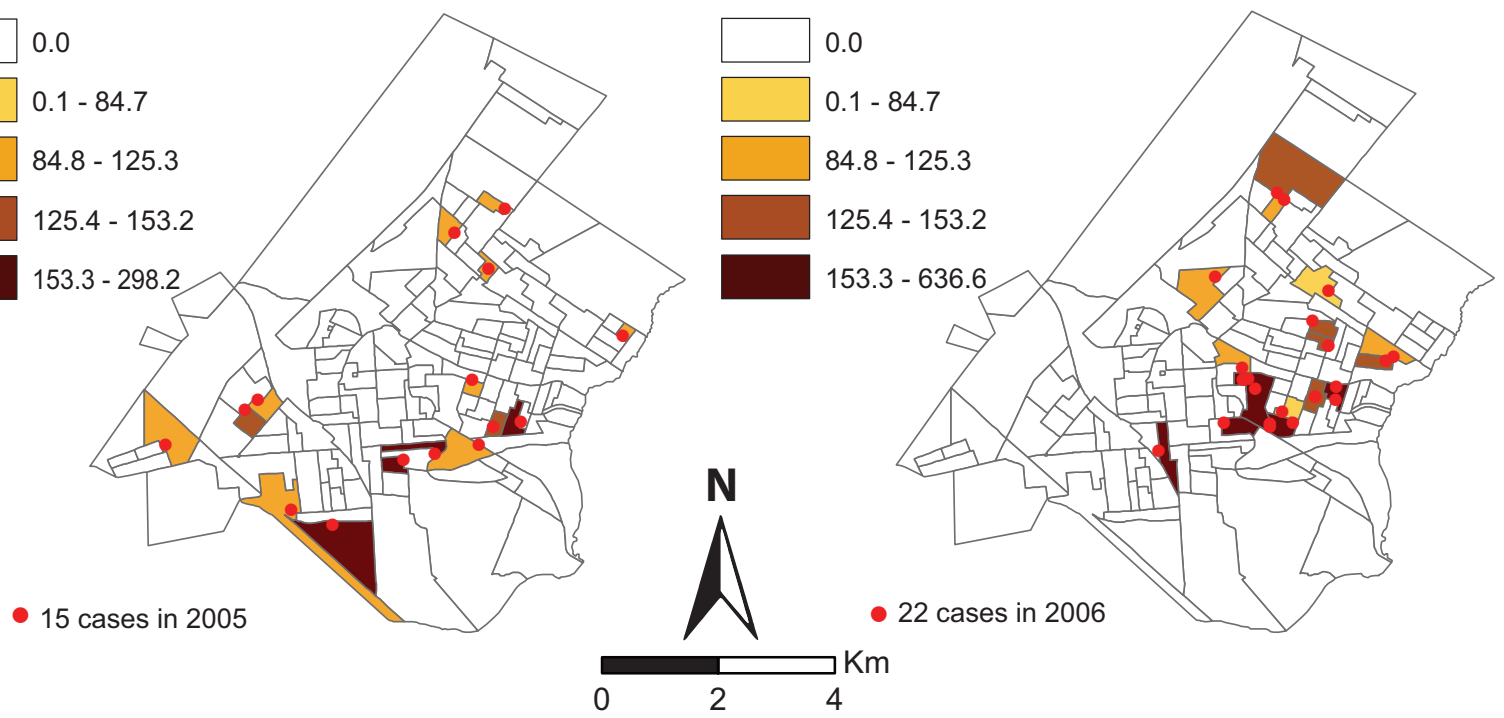

- 15 cases in 2005

(F)

FIGURE 3 - Incidence rates (per 100,000 inhabitant-years) and new cases of visceral leishmaniasis in humans (VLH) by urban census tract and year, 1999-2006, Birigui, State of São Paulo, Brazil. 
Incidence rate $\mathbf{- 2 0 0 7}$

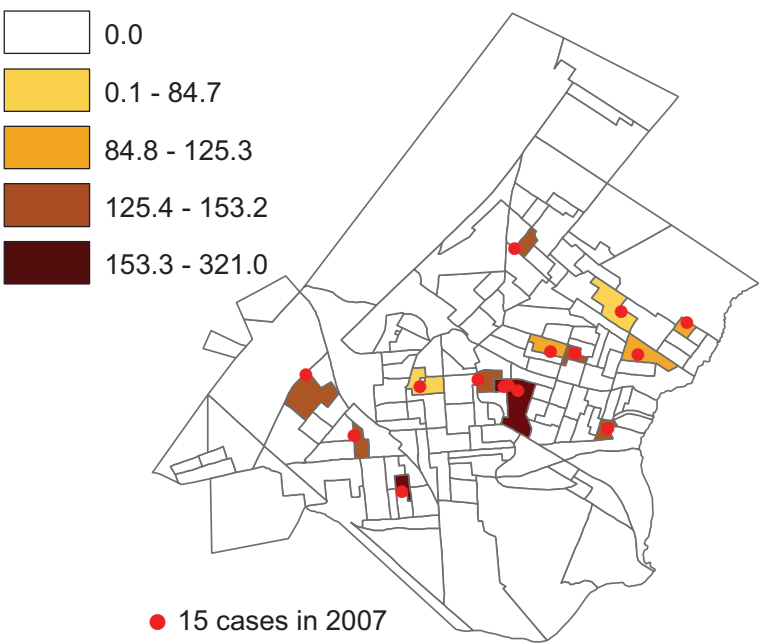

Incidence rate - 2009

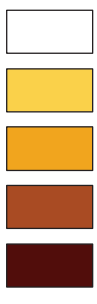

(C)
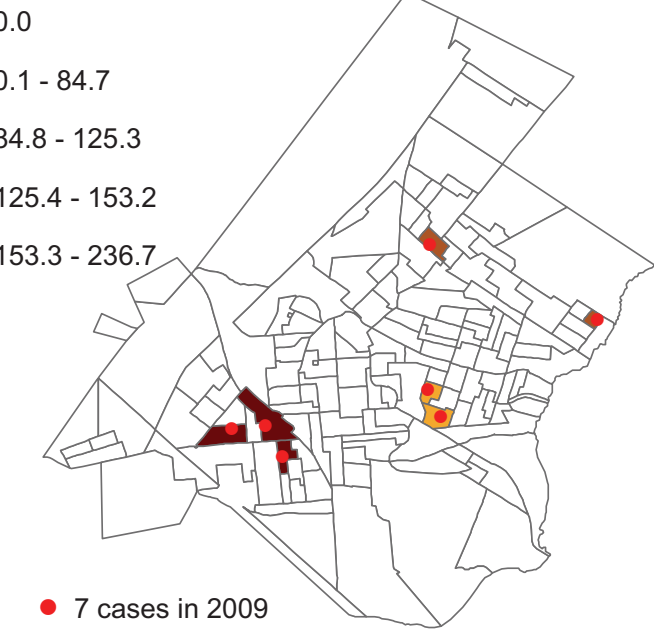

Incidence rate - 2011

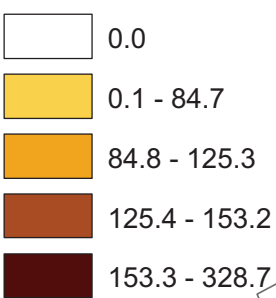

(E)

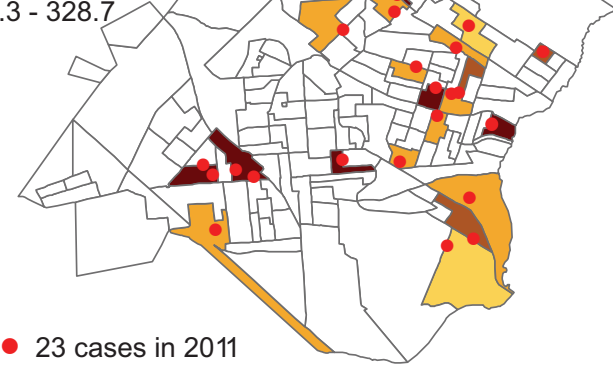

23 cases in 2011
Incidence rate - 2008

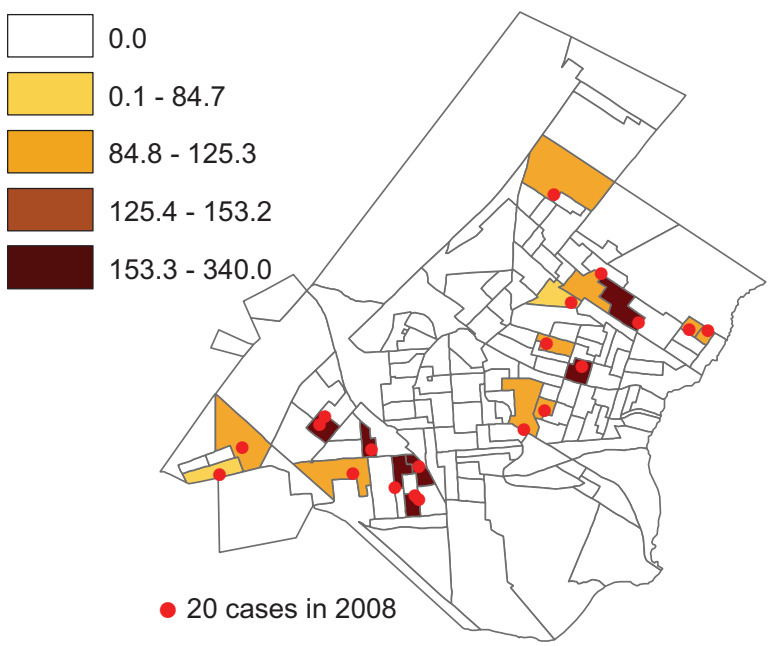

(B)

Incidence rate - 2010

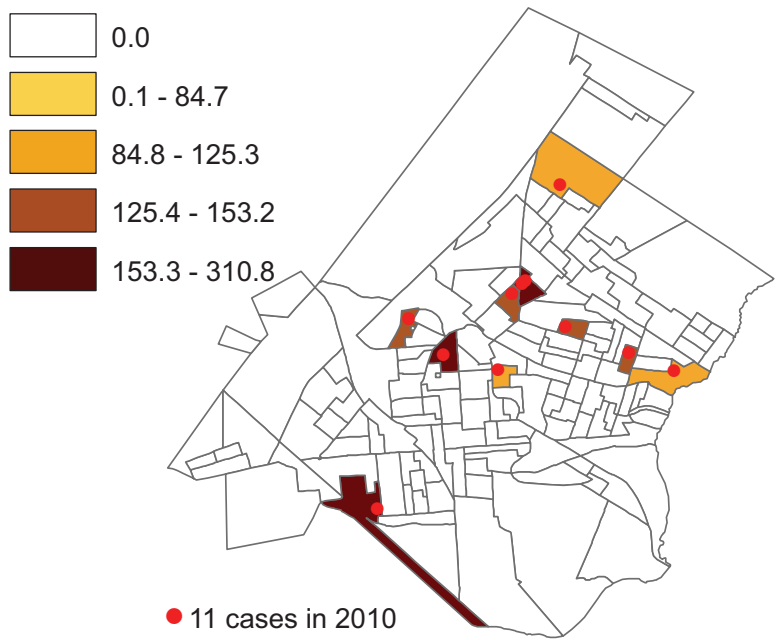

(D)

Incidence rate - 2012

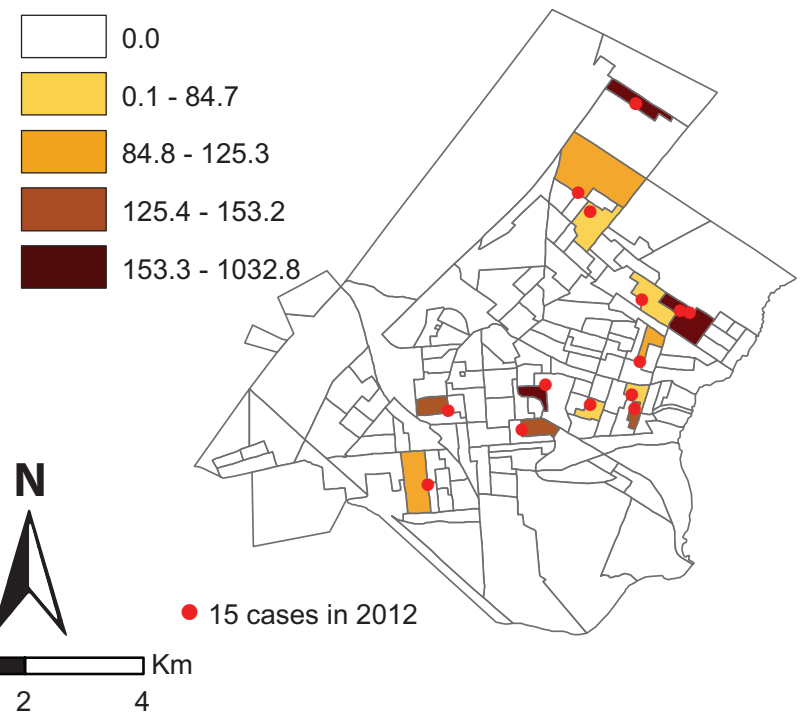

FIGURE 4 - Incidence rates (per 100,000 inhabitant-years) and new cases of visceral leishmaniasis in humans (VLH) by urban census tract and year, 2007-2012, Birigui, State of São Paulo, Brazil. 


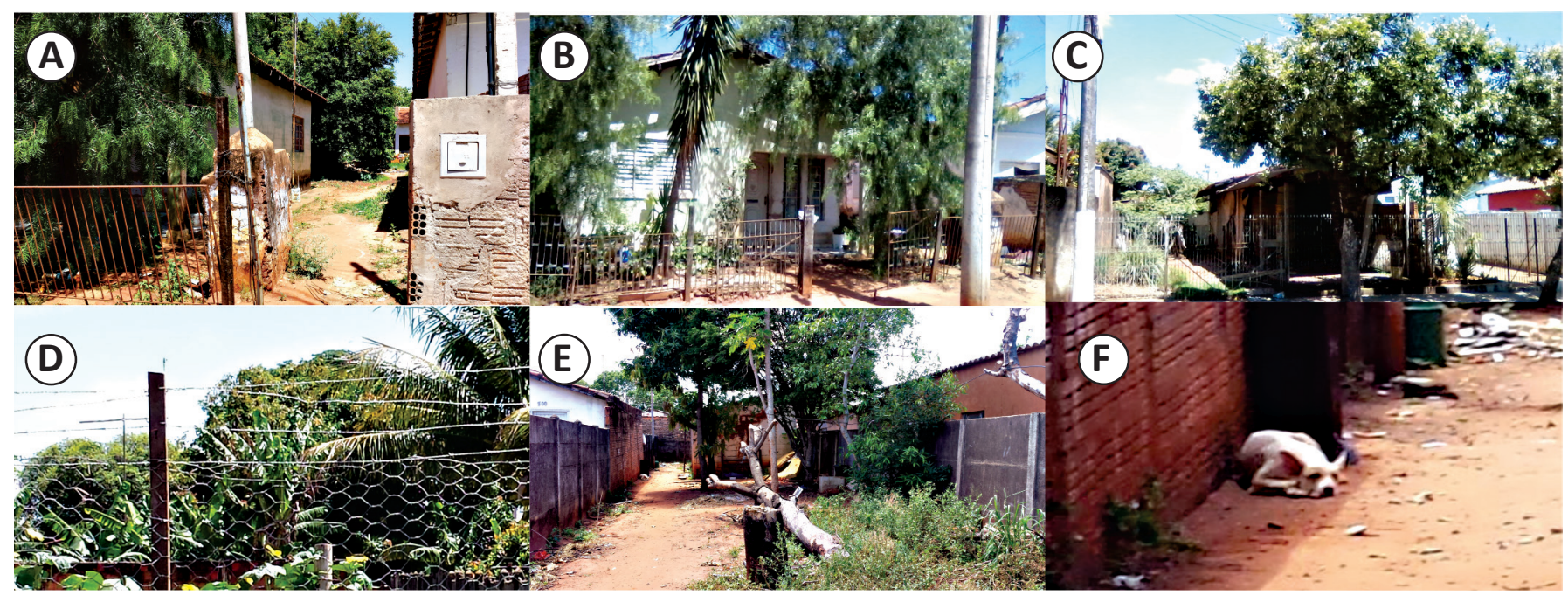

FIGURE 5 - Representative photos of houses corresponding to the spatial and spatio-temporal clusters, Birigui, State of São Paulo, Brazil. Figure 5F represents the enlarged details of Figure 5E, which shows the reservoirs (dogs) in their home environment.

of the study (1999-2012). The first reported cases were identified in the central region of the county. Over the years, the distribution of cases has expanded among the census tracts, reaching the outlying regions of the city and simultaneously occurring in the city center. We observed a variation in the incidence rates of VLH that was expressed from year to year and among the census tracts; there was also an increase in the incidence rates surrounding the years with incidence peaks (2006 and 2011). In 2012, there was a higher incidence rate of VLH in a census tract compared with other years.

From the scan statistics, spatial clusters were identified throughout the study period and encompassed five census tracts with a total of 20 cases of VLH; this was a statistically significant result [relative risk $(\mathrm{RR})=3.59, \mathrm{p}<0.05]$ (Figure 2E). A spatiotemporal cluster was also identified from February 2006 to September 2012, encompassing 44 census tracts and a total of 59 cases of VLH; this was a statistically significant result $[R R=3.58, p<0.05]$ (Figure 2F). Furthermore, the spatiotemporal cluster included the two annual incidence peaks of VLH.

The Birigui areas that were classified as spatial and spatiotemporal clusters of VLH cases were visited, and these areas had ground-level houses in which low income and average income families live. Several of these houses had shaded backyards due to the presence of bushes and fruit trees (mango, jaboticaba tree, banana, mulberry, acerola tree, etc.). The majority of the homes had dogs, and some homes also had chickens and horses. In some parts of the cluster areas, there were dogs in the streets (Figure 5 - features homes or homes with VLH cases).

\section{DIscussion}

The analysis of the occurrence of VLH in Birigui allowed for the visualization of several important characteristics of the disease, including the observation that the population aged 0 to
4 years ${ }^{15}$ had a much higher incidence of VLH than other age groups. According to Xavier-Gomez et al. ${ }^{1}$, the immaturity of humoral and cellular immunity makes children more susceptible to infections.

Studies by Silva and Gaioso ${ }^{16}$ and Goes et al. ${ }^{17}$ compared the incidence of VLH between sexes and found a predominance of male cases, which was not observed in Birigui. This inconsistency might be related to a potentially greater exposure to the vector in the male population because males are more likely to perform activities in rural and sylvatic environments ${ }^{16,17}$. This was not the case in Birigui during the study period because the disease occurred mainly in urban areas; this finding might have favored the more equal incidence rates between the sexes.

When the incidence rates of VLH in Birigui were distributed among their respective age groups, it was observed that the sex balance masks other significant differences. The higher incidence observed in girls 0-4 years old compared with boys of the same age group differs from other studies that reported no differences in susceptibility to VLH between the sexes ${ }^{15,18}$. In contrast, Costa ${ }^{19}$ reported a higher susceptibility in male children younger than five years of age because of the hormonal characteristics of the sex; these differences have not yet been explained. Visceral leishmaniasis in humans has been described as an opportunistic disease in human immunodeficiency virus (HIV) infected individuals. This coinfection might be related to the higher incidence of the disease in males aged 20-60 years compared with females because this age group has the highest percentage of HIV-positive individuals ${ }^{20}$.

Despite the large number of cases in the 0-4-year-old age group, the case fatality rate in that age group was low. Case fatality rates peaked among persons aged 60 and older perhaps because of the combination of VLH and other diseases previously acquired in this age group. Additionally, adverse reactions caused by medications used to treat VLH occur more frequently in the older age group, and elderly persons are more likely to have impaired immunity ${ }^{3,21}$. 
Differences were observed when comparing the curves of incidence between the municipality of Birigui and the AR of Araçatuba during the study period. There was a steady increase in incidence rates in the AR from 1999 to 2003, which was followed by a continuous downward trend in incidence ${ }^{10}$. Although the incidence decreased in the AR of Araçatuba, Birigui presented increasing rates that spiked in 2006 and $2011^{10}$. These two peaks might be related to the cyclic behavior expected for this disease and to variations in the level of application of control measures in Birigui. The differences between Birigui and the AR of Araçatuba might be related to the lack of effective VL surveillance and control measures and the less extensive implementation of these measures in Birigui compared with other municipalities in the AR of Araçatuba.

Werneck et al. ${ }^{22}$ and Souza et al. ${ }^{23}$ questioned the effectiveness of the measures recommended by the National Control Plan for Visceral Leishmaniasis (PNCLV) and suggested that these measures did not provide satisfactory results. Their main questions were regarding the difficulties observed in most municipalities and were related to the problem of asymptomatic dogs; infections in these animals are generally not detected and contribute to the maintenance of the disease cycle. Furthermore, Moreira Jr et al. ${ }^{24}$ suggested problems related to the low stability and sensitivity of the assays used to detect the infection in dogs, the long period between diagnosis and canine euthanasia, the resistance of the owners in relation to the euthanasia procedure, and the rapid replacement of the dogs.

Several authors have indicated that when performed with continuity and regularity, the combination of surveillance and control measures, such as environmental education, early diagnosis, treatment of human patients, early diagnosis, removal of infected and diseased animals and vector control, are the most effective ways to control VL and decrease the incidence rates of $\mathrm{VLH}^{25-27}$.

The differences detected in the incidence curves between Birigui and the other municipalities of the AR of Araçatuba represent a good opportunity to assess whether the measures recommended by the PNCLV are effective. Additionally, it is possible to evaluate whether the coverage of surveillance and control measures and the quality with which these measures are executed correspond to the different epidemiological figures found in the AR of Araçatuba. These issues would be the subjects of a future study.

The geocodification of the notified VLH cases allowed for the calculation of rates by census tracts, the investigation of the spatial and spatiotemporal patterns of the disease in Birigui, and the identification of areas of greatest risk for incidence in space and time. These results demonstrate that spatial analysis tools have important value for epidemiological analyses and the improvement of surveillance, disease control and public policy development ${ }^{9}$. A joint action of the measures recommended by the Health Ministry and the utilization of geo-referencing enables greater efficiency and effectiveness in controlling disease and might be a tool for reducing the incidence of VLH in Birigui ${ }^{10}$ and other municipalities with similar epidemiological frameworks.
After the identification of the spatial and spatiotemporal clusters, and as a result of the visits carried out in these areas, a close relationship between humans and dogs and other domestic and breeding animals in these clusters was verified. Additionally, organic matter is present, which creates ideal conditions for the vector, and the families living in these regions are of low socioeconomic status. The combination of these factors characterizes these clusters as high-risk areas for the occurrence of disease ${ }^{28,29}$ and confirms the results obtained by the spatial and spatiotemporal analyses. These characteristics are factors that interact in the ecology of the disease and have already been detected and observed in other regions of Brazil ${ }^{30}$. In recent years, these characteristics have contributed to the vast expansion of VL in the State of São Paulo ${ }^{10}$ and throughout the country.

Limitations to this study include the use of secondary data and the problems inherent to secondary, such as incompleteness and inconsistency of information and possible underreporting of cases. These limitations were minimized because we were able to geocode $98 \%$ of VLH urban cases; empirical Bayesian rates were also used. The application of this technique allowed for the identification of disease prevalence in all sectors of the city and allowed for the assessment of underreporting ${ }^{31,32}$.

Birigui, a municipality belonging to the AR of Araçatuba, has recently experienced an increase in VLH cases. This increase is contrary to the behavior observed throughout the entire Araçatuba region, which has shown a declining trend in VLH incidence. The observations that the highest incidence is in children 0-4 years old and the highest mortality rate is in people 60 years and older are in line with the expected patterns of this disease. The use of spatial analysis tools in this study facilitated the identification of areas of high risk for the occurrence of VLH and demonstrated the presence of VLH in all of the urban census tracts in the city.

\section{CONFLICT OF INTEREST}

The authors declare that there is no conflict of interest.

\section{FINANCIAL SUPPORT}

Fundação de Amparo à Pesquisa do Estado de São Paulo (FAPESP) 2010/20279-1 and FAPESP 2012/17564-1.

\section{REFERENCES}

1. Xavier-Gomes LM, Costa WB, Prado PF, Oliveira-Campos M, Leite MTS. Características clínicas e epidemiológicas da leishmaniose visceral em crianças internadas em um hospital universitário de referência no norte de Minas Gerais, Brasil. Rev Bras Epidemiol 2009; 12:549-555.

2. Pan American Health Organization (PAHO). Regional Office of the World Health Organization. [Internet] Leishmaniases: Epidemiological Report of the Americas 2013; n 1, April. [Cited 2013 October 15]. Available from: http: //www.paho.org/leishmaniasis/.

3. Karagiannis-Voules DA, Scholte RGC, Guimarães LH, Utzinger J, Vounatsou P. Bayesian geostatistical modeling of leishmaniasis incidence in Brazil. PLoS Negl Trop Dis 2013; 7:e2213. 
4. Maldosso G, Fortaleza CM, Ribeiro NA, Cruz LL, Nogueira PA, Lindoso JAL. American Visceral Leishmaniasis: Factors associated with lethality in the state of São Paulo, Brazil. J Trop Med 2012; 2012:1-7.

5. Nascimento BWL, Saraiva L, Teixeira Neto RG, Serra e Meira PCL, Sanguinette CC, Tonelli GB, et al. Study of sand flies (Diptera:Psychodidae) in visceral and cutaneous leishmaniasis area in central western of Minas Gerais State, Brazil. Acta Tropica 2013; 125:262-268.

6. Alves WA. Leishmaniose visceral americana. Situação atual no Brasil. Bepa 2009; 6:25-29.

7. Costa JML. Epidemiologia das Leishmanioses no Brasil. Gazeta Médica da Bahia 2005; 75:3-17.

8. Costa AIP, Casanova C, Rodas L, Galati EAB. Atualização da distribuição geográfica e primeiro encontro de Lutzomyia longipalpis em área urbana no estado de São Paulo, Brasil. Rev Saúde Pública 1997; 31:623-633.

9. Camargo-Neves VLF, Katz G, Rodas LAC, Poletto DW, Lage LC, Spínola RMF, et al. Utilização de ferramentas de análise espacial na vigilância epidemiológica de leishmaniose visceral americana Araçatuba, São Paulo, Brasil, 1998-1999. Cad Saude Pública 2001; 17: 1263-1267.

10. Cardim MFM, Rodas LAC, Dibo MR, Guirado MM, Oliveira AM, Chiaravalloti-Neto F. Introdução e expansão da Leishmaniose visceral americana no estado de São Paulo, 1999 a 2011. Rev Saude Publica 2013; 47: 691-700.

11. Superintendência de Controle de Endemias do Estado de São Paulo (SUCEN). [Internet] Vector-Informativo Sucen 2012; (11):09-10. [Cited 2013 October 13]. Available from: http://www.saude.sp.gov.br/resources/ sucen/homepage/downloads/arquivos-dovector/vector_11.pdf/.

12. Centrode Vigilância Epidemiológica "Professor Alexandre Vranjac" [Internet]. [Cited 2013 October 9]. Available from: http://cve.saude. sp.gov.br/.

13. Câmara G, Carvalho MS, Cruz OG, Correa V. Análise espacial de áreas. In: Druck S, Carvalho MS, Câmara G, Monteiro AMV, editors. Análise Espacial de dados geográficos. Brasília: Embrapa Cerrados; 2004. p. 155209.

14. Kulldorf M. SaTScan user guide for version 8.0, 2009 [Internet]. [Cited 2013 October 10]. Available from: http://www.satscan.org/.

15. Barbosa IR, Costa ICC. Aspectos clínicos e epidemiológicos da leishmaniose visceral em menores de 15 anos no estado do Rio Grande do Norte, Brasil. Sci Med 2013; 23: 5-11.

16. Silva ES, Gaioso ACI. Leishmaniose visceral no estado do Pará. Study conducted at the State Department of Public Health of Pará (SESPA). Belém, Pará: Secretaria Estadual de Saúde do Pará; 2013.

17. Goés MAO, Melo CM, Jeraldo VLS. Série temporal da leishmaniose visceral em Aracaju, estado de Sergipe, Brasil (1999 a 2008): aspectos humanos e caninos. Rev Bras Epidemiol 2012; 15:298-307.
18. Queiroz MJA, Alves JGB, Correia JB. Leishmaniose visceral: características clínico-epidemiológicas em crianças de área endêmica. J Pediatr 2004; 80:141-146.

19. Costa CHN, Pereira HF, Araújo MY Epidemia de leishmaniose visceral no Estado do Piauí, Brasil, 1980-1986. Rev Saude Publica 1990; 24:361-372.

20. Carvalho FL, Aires DLS, Segunda ZF, Azevedo CMPS, Corrêa RGCF, Aquino DMC, et al. Perfil epidemiológico dos indivíduos HIV positivo e coinfecção HIV-Leishmania em um serviço de referencia em São Luís, MA, Brasil. Ciênc. Saude Coletiva 2013; 18:1305-1312.

21. Botelho ACA, Natal DA. Primeira descrição epidemiológica da leishmaniose visceral em Campo Grande, Estado de Mato Grosso do Sul. Rev Soc Bras Med Trop 2009; 42:503-508.

22. Werneck GL, Pereira TJCF, Farias GC, Silva FO, Chaves FC, Gouvêa MV, et al. Avaliação da efetividade das estratégias de controle da leishmaniose visceral na cidade de Teresina, Estado do Piauí, Brasil: resultados do inquérito inicial-2004. Epidemiol Serv Saude 2008; 17:87-96.

23. Souza VMM, Julião FS, Neves RCS, Magalhães PB, Bisinotto TV, Lima AS, et al. Ensaio comunitário para avaliação da efetividade de estratégias de prevenção e controle da leishmaniose visceral humana no município de Feira de Santana, Estado da Bahia, Brasil. Epidemiol Serv Saude 2008; 17:97-106.

24. Moreira Jr ED, Souza VMM, Sreenivasan M, Nascimento EG, Carvalho LCP. Assessment of an optimized dog-culling program in the dynamics of canine Leishmania transmission. Vet Parasitol 2004; 122:245-252.

25. D'Andréa LAZ. Leishmaniose visceral americana - Análise das estratégias de controle da doença na micro-região de Dracena na Alta Paulista/SPBrasil. [Dissertation]. [São Paulo]: Universidade do Oeste Paulista; 2008.

26. Gontijo CMF. Leishmaniose visceral no Brasil: quadro atual, desafios e perspectivas. Rev Bras Epidemiol 2004; 7:338-349.

27. Scandar SAS, Silva RA, Cardoso-Junior RP, Oliveira FH. Ocorrência de leishmaniose visceral americana na região de São José do Rio Preto, Estado de São Paulo, Brasil. Bepa 2011; 8:13-22.

28. Mestre GLC, Fontes CJF. A expansão da epidemia da leishmaniose visceral no estado de Mato Grosso, 1998-2005. Rev Soc Bras Med Trop 2007; 40:42-48

29. Oliveira JM, Fernandes AC, Dorval MEC, Alves TP, Fernandes ID, Oshiro ET, et al. Mortalidade por leishmaniose visceral: aspectos clínicos e laboratoriais. Rev Soc Bras Med Trop 2010; 43:188-193.

30. Sherlock, IA. Ecological interactions of visceral leishmaniasis in the State of Bahia, Brazil. Mem Inst Oswaldo Cruz 1996; 91:671-683.

31. Maia-Elkhoury ANS, Carmo EH, Sousa-Gomes ML, Mota E. Análise dos registros de leishmaniose visceral pelo método de captura-recaptura. Rev Saude Publica 2007; 41:931-937.

32. Souza WV, Barcellos CC, Brito AM, Carvalho MS, Cruz OG, Albuquerque MFM, et al. Aplicação de modelo bayesiano empírico na análise espacial da ocorrência de hanseníase. Rev Saude Publica 2001; 35:474-480. 